\title{
DIAGNOSI DI INFEZIONE DA HPV: PCR NESTED E SEQUENZIAMENTO DIRETTO vs DIGENE HYBRID CAPTURE 2 (HC2).
}

Longo R.', Cappiello G.', Schiavone M.L.', Visca M.', Ursitti A.', Romano S.', Pontani G. ${ }^{2}$, Spanò A.'

'U.O.C. Microbiologia Virologia e Immunologia

Ospedale S. Pertini - Roma,

'U.O. Citodiagnostica ASL RM-B

Premessa. Benché gli HPV ad alto rischio oncogeno siano gli agenti eziologici maggiormente implicati nella cancerogenesi cervicale, l'acquisizione di dati epidemiologici riguardanti genotipi di nuova scoperta, rari e/o di incerta classificazione rende auspicabile poter diagnosticare le infezioni sostenute da tutti i genotipi virali.

Obiettivo. Valutare le performance di una PCR home-made rispetto ad un test commerciale ( $\mathrm{HC}_{2}{ }^{\circledast}$, Digene) basato sull'ibridazione diretta in fase liquida per la diagnosi d'infezione e la tipizzazione virale.

Materiali e metodi. Ciascun campione (cellule esfoliate dalla cervice uterina raccolte e conservate nel terreno liquido Surepath $^{\mathrm{TM}}$ ) era sottoposto sia al HC2 sia ad una PCR nested (nPCR), previa estrazione del DNA (QIAgen), utilizzando i primer My09/My11 e GP5+/6+ per la regione genomica codificante la proteina capsidica L1; la positività in PCR era seguita dal sequenziamento diretto.

Risultati. Su 103 campioni analizzati, 51 (49,5\%) erano positivi ad almeno un test: 30 erano positivi al HC2 e 50 alla nPCR. 29 campioni erano positivi concordanti ad entrambi i test; di questi, 9 erano discordanti riguardo alla tipizzazione. 21 campioni erano positivi alla nPCR e negativi al HC2; di questi, 9 erano genotipi ad alto rischio $(16,18,31,39,52,53)$.

Un campione era negativo alla $\mathrm{nPCR}$ e positivo al HC2.

Discussione. L'utilizzo di primer noti per la capacità di individuare uno spettro ampio di genotipi permette di diagnosticare infezioni ad alto/basso/incerto rischio oncogeno laddove il test $\mathrm{HC} 2$ darebbe risultati falsi negativi.

L'HC2 non prevede come target genotipi di frequente riscontro nella popolazione italiana $(53,66,54,70,73)$.

E' noto che alcune sonde possono cross-ibridare con genotipi non specificamente rilevabili con 1'HC2 $(53,66,70)$ ma ciò potrebbe incidere negativamente sul limite di sensibilità del metodo.

Tale cross-ibridazione può inoltre generare errori di tipizzazione.

Benché il sequenziamento diretto non permetta di evidenziare tutte le coinfezioni, la nPCR sembra avere una sensibilità e una specificità più elevate rispetto $\mathrm{al} \mathrm{HC} 2$. 